\title{
Gra z efektem R(ealizmu). Wprowadzenie do twórczości teatralnej Thomasa Ostermeiera ${ }^{1}$
}

\author{
DOI: http://dx.doi.org/10.12775/LC.2018.025
}

\begin{abstract}
Streszczenie: Artykuł prezentuje twórczość Thomasa Ostermeiera na tle przemian niemieckiego teatru po 1989 roku. Twórca związany z berlińską Schaubühne am Lehniner Platz uprawia swój teatr w kontrze do postmodernistycznej dekonstrukcji i postdramatycznego performowania, czyli dominujących estetycznych paradygmatów niemieckiego teatru w ostatnich dekadach. Dla niego teatr jest nade wszystko forum krytycznej autorefleksji (a nie izolowanej, estetycznej autoreferencyjności), samokrytycznego przesłuchania samych siebie i świata wokół nas, rewizji pewnych siebie pozycji, wszystkich truizmów podzielanych przez społeczeństwo, które nas otacza i warunkuje. Te kluczowe wartości polityczne twórczości teatralnej Ostermeiera łączy pojęcie „realizmu”. Do Brechtowskiego zaangażowania politycznego dodaje podejście estetyczne wywiedzione z tradycji Maxa Reinhardta, a oparte na założeniu, że każdy dramat wymaga specyficznego reżyserskiego podejścia i sposobu inscenizowania.
\end{abstract}

Słowa kluczowe: Thomas Ostermeier, teatr niemiecki, efekt realności, teatr reżyserów, nowe mieszczaństwo

\section{Playing with the R(ealism) effect. An introduction to Thomas Ostermeier theatre work}

\footnotetext{
Abstract: The article presents the theatre work of Thomas Ostermeier in the context of the German's theatre transformation after 1989. The director involved in the Schaubühne am Lehniner Platz in

* Profesor Uniwersytetu w Kent (USA), związany z International Research College, współtwórca European Theatre Research Network. Zainteresowania badawcze: współczesna reżyseria teatralna, dramat XX/XXI wieku, przenikanie się estetyki i polityki w sztukach performatywnych. E-mail:.....

1 Ten tekst stanowi pierwszy rozdział książki Petera M. Boenischa i Thomasa Ostermeiera The Theatre of Thomas Ostermeier, wydanej w 2016 roku przez wydawnictwo Routlegde. Dziękujemy wydawnictwu za wyrażenie zgody na publikację tekstu na łamach "Litterariów Copernicanów”.
} 
Berlin create his theatre against postmodern deconstruction and postdramatic performing, German theatre's prevalent aesthetic paradigms in recent decades. Above all the theatre is for him a forum for critical self-reflection (not an aethetically secluded self-reflection), the self-critical interrogation of our selves and of the world around us, the revision of self-confidence, of all apparently self-evident thruths in an of the society that surround and conditions us. These values of Ostermeier's work units these essentially political core of his theatre in the notation of "realism". For Brecht's political theatre, he adds an aesthetic approach derived from Max Reinhardt's tradition, based on the assumption that each play demands its specific directorial approach and staging.

Keywords: Thomas Ostermeier, German Theatre, realism effect, Regietheater, a New Middle Class

aden inny niemiecki zespół teatralny i żaden współczesny niemiecki artysta teatru nie jest tak mocno obecny na świecie jak Thomas Ostermeier (ur. 1968) i jego berlińska Schaubühne am Lehniner Platz, którą kieruje jako dyrektor artystyczny od jesieni 1999 roku, wypełniając cztery usytuowane przy Kurfürstendamm sceny stałym repertuarem obejmującym w sumie pięćset przedstawień w sezonie. Zespół gra także w każdym roku około stu spektakli za granicą. W trakcie sezonu teatralnego 2014/2015 inscenizacje Schaubühne poza Berlinem obejrzało prawie sześćdziesiąt osiem tysięcy widzów - oczywiście nie tylko samego Ostermeiera, ale głównie wyreżyserowane przez niego. Między lipcem 2014 i 2015 roku zespół pojechał do Awinionu (gdzie otworzył i zamknął sezon spektaklami na słynnym festiwalu), Oslo, Londynu, Seulu, Dublina, Moskwy (z trzech okazji i z trzema różnymi produkcjami), Belfastu, Cluj Napoca, Amsterdamu (z dwoma przedstawieniami z dwóch okazji), Lozanny, Delhi, Kalkuty i Madras, Sao Paulo, Rennes, Montrealu, Wiesbaden, Makau, Recklinghausen, Tiencinu i Pekinu (z dwiema produkcjami), Neapolu, Aten, Paryża, Lizbony i Wenecji (z dwoma spektaklami na biennale). W rezultacie tej globalnej obecności teatr Thomasa Ostermeiera, w szczególności jego własne, globalnie fetowane inscenizacje, takie jak Hedda Gabler (2005), Matżeństwo Marii Braun (2007/2014), Hamlet (2008), Wróg ludu (2012), Little Foxes (2014) i Ryszard III (2015), reprezentowały niemiecki teatr w szerokim świecie, daleko poza Europą. W 2011 roku w wieku czterdziestu trzech lat stał się Ostermeier najmłodszym w historii laureatem Złotego Lwa podczas Biennale w Wenecji, nagrody, którą otrzymał za całokształt osiągnięć. Był ku temu dobry powód, niemiecki tygodnik „Die Zeit” uznał go za „twarz współczesnego teatru niemieckiego" (Lebert 2011: 14).

Nie ma chyba mniej typowego dla współczesnego niemieckiego teatru reżysera niż Ostermeier. W ostrym kontraście z jego popularnością u widzów zagranicznych i w Berlinie (w Schaubühne bilety na jego spektakle regularnie są wyprzedane już w pierwszym dniu sprzedaży) stoją opinie niemieckiej krytyki. Po początkowym szumie wokół jego pracy reżyserskiej w Die Baracke, którą to scenę prowadził od 1996 roku, recenzenci rzadko traktowali bez chłodu nawet jego najbardziej uznane dzieła, takie jak Hamlet. Od przejęcia Schaubühne w 1999 roku Ostermeier otrzymał tylko trzy nominacje do udziału w berlińskich Theatertreffen, corocznym festiwalu prezentującym dziesięć najlepszych spektakli 
sezonu wybranych przez jury złożone z krytyków teatralnych² ${ }^{2}$ Porównując berlińskie recenzje jego niedawnego Ryszarda III (2015) z recepcją krytyczną we Francji (gdzie występ w Awinionie trafił na pierwsze strony gazet, m.in. „Le Monde”), można zauważyć zaskakującą rozbieżność. W rodzinnym kraju inscenizacje Ostermeiera zdają się prześlizgiwać przez oka sieci kategorii krytycznych głównego nurtu, a niemieccy teatrolodzy także w zasadzie milczą na temat jego twórczości ${ }^{3}$. W odróżnieniu od wielu artystów teatralnych z kraju, który wynalazł Regietheater, „teatr reżyserów”, jego twórczość nie daje się łatwo podsumować za pomocą garści estetycznych zasad, które powtarzają się w produkcjach innych artystów. Na pierwszy rzut oka przynajmniej wydaje się, że brak mu znaku firmowego, „reżyserskiej sygnatury”. Mimo że nadaje dramatom Henryka Ibsena, Williama Szekspira, Lillian Hellman i Tennessee Williamsa wyraźnie współczesny feeling, Ostermeier trzyma się z dala od idiosynkratycznych, autorskich interpretacji. Są tu oczywiście wszystkie cechy rozpoznawcze niemieckiego Regietheater, które najbardziej profesjonalni i akademiccy krytycy uznają za probierz osiągnięć artystycznych, ale perspektywa angloamerykańska, mająca tendencję do ujmowania jego twórczości w kategoriach reżysera-autora, pomija kluczowe zasady i wartości jego spektakli, które zostaną tutaj zarysowane.

Sam Ostermeier sytuuje swoje podejście do teatru przede wszystkim poza, po i w kontrze do postmodernistycznej dekonstrukcji i postdramatycznego performowania, czyli dominujących estetycznych paradygmatów niemieckiego teatru w ostatnich dekadach. Przede wszystkim odrzuca estetycznie autoreferencyjną teatralność rozpowszechnioną we współczesnym teatrze (niemieckim i nie tylko). W jego analizie wiele z tych praktyk utknęło w epigońskich kliszach dekonstrukcji, tracąc już dawno większość, jeśli nie cały impet krytyczny, który napędzał postmodernistyczne prowokacje przeciw modernistycznym pewnikom, idące w ślad za rewoltą roku 1968, jak to wyartykułowali Michel Foucault i Jacques Derrida. Ostermeier określa samego siebie jako „młodszego brata dekonstrukcjonistów”, który zajmuje się sprzątaniem po nich (Jörder 2014: 9)4 . Dla niego teatr jest nade wszystko forum krytycznej autorefleksji (a nie izolowanej, estetycznej autoreferencyjności), samokrytycznego przesłuchania samych siebie i świata wokół nas, rewizji pewnych siebie pozycji, wszystkich truizmów podzielanych przez społeczeństwo, które nas otacza i warunkuje. Kluczowe teksty o teatrze pisane od końca lat 90. do dziś czynią jego zasadniczą intencję jasną. Ostermeier łączy te kluczowe wartości polityczne swojej twórczości teatralnej w pojęciu „realizmu” stanowiącym fundament jego pracy. Rozumie pojęcie „realizmu” jako coś zupełnie odmiennego od teatralnego „realizmu kuchennego zlewu” czy zwyczajnego naturalizmu. Manifest Schaubühne zatytułowany Misja (Der Auftrag), którym Ostermeier i jego współdyrektorka w tamtym czasie, choreografka Sasha Waltz, rozpoczy-

\footnotetext{
2 Został zaproszony z Domem lalki, Heddq Gabler oraz Małżeństwem Marii Braun, pierwotnie zrealizowanym dla Kammerspiele w Monachium, a później przeniesionym do Schaubühne.

3 Pierwsza niemieckojęzyczna książka o jego teatrze to zbiór wywiadów Backstage Ostermeier, zredagowany przez zasłużonego krytyka teatralnego Gerharda Jördera (Berlin 2014, seria "Theater der Zeit"). Dwie pierwsze monografie akademickie o Ostermeierze zostały wydane po francusku: Pelechová, Jitka 2013. Le Théâtre de Thomas Ostermeier. Louvain: Études Théâtrales. Vol. 58; Banu, Georges, Jitka Pelechová 2016. Le théâtre et la peur /Thomas Ostermeier. Actes Sud.

${ }^{4}$ Ostermeier opisuje siebie jako osobę składającą z powrotem rozsypane elementy, ale w taki sposób, że rysy i pęknięcia pozostają widoczne. „Japońska kultura ma na to odpowiednie określenie: kintsugi. Naczynie ceramiczne jest najpiękniejsze, kiedy zostaje rozbite i zrekonstruowane. Celem tej estetyki jest uczynienie pęknięć widocznymi" (Jörder 2014: 9).
} 
nali kadencję w styczniu 2000 roku, podsumowuje zwięźle zestaw tych „neorealistycznych” podstaw ${ }^{5}$ :

Teatr może być jednym z tych miejsc, gdzie próby rozumienia świata na różne sposoby intensyfikują się ku wspólnemu światopoglądowi i wspólnej postawie życiowej. Teatr może być dla społeczeństwa przestrzenią uzyskiwania świadomości, a więc ma być na powrót upolityczniony.

Do tego celu potrzebujemy współczesnego teatru $[\ldots]$. Potrzebujemy nowego realizmu, ponieważ realizm przeciwdziała „fałszywej świadomości”, która w dzisiejszych czasach oznacza raczej brak jakiejkolwiek świadomości. Realizm nie jest zwykłym obrazem świata takiego, na jaki wygląda. Jest spojrzeniem na świat w postawie, która domaga się zmiany (Tageszeitung 2000: 15$)^{6}$.

Ostermeiera idea realizmu nie może być dalsza od reprezentacji wartości nominalnej, rzeczywistości literalnych, które w swojej rozpoznawalności afirmują świat taki, jaki wierzymy, że jest nam znany. Przeciw „realizmowi kapitalistycznemu” oper mydlanych w mediach głównego nurtu, także przeciw postdramatycznej praktyce performatywnej, jego materialistyczny realizm używa poczucia „autentyczności”, aby skonfrontować widzów z pewnymi głębokimi, być może nawet wypartymi konfliktami i sprzecznościami w sercu współczesnego społeczeństwa. W nastawieniu wyglądającym czasami na niemodne jego teatr podtrzymuje wartości społeczeństwa mieszczańskiego - wolność, równość, braterstwo - łącząc je z wiarą w humanizm oświecony i Brechtowską utopię, wiary w to, że rozpoznanie sprowokowane przez denaturalizację naszej standardowej percepcji może przynieść refleksję, wgląd, krytyczną postawę, a nawet potencjalnie akt zmiany. W czasach Die Baracke Ostermeier głosił: „Po zwycięstwie komunizmu teatr stanie się zbędny” (Burckhardt 1998: 102). W duchu tych pojęć, głęboko pod powierzchnią estetyki, intencji i interpretacji, teatr Ostermeiera rzeczywiście odkrywa zaskakująco logiczną drogę, która prowadzi wprost od jego wczesnych spektakli w Die Baracke, gdzie wystawiał głównie dramaty angloamerykańskich nowych brutalistów, do jego obecnych inscenizacji klasyki dramatu i współczesnych sztuk w Schaubühne.

Głównym motorem prowokującym to rozpoznanie i defamiliaryzację perspektywy normatywnej jest w jego teatrze tekst dramatyczny ${ }^{7}$. Reżyserskie podejście Ostermeiera [...] wciąż pozostaje $\mathrm{w}$ zgodzie z niektórymi fundamentalnymi zasadami, które wyartykułował w 1998 roku. Przede wszystkim jako reżyser wierzy bezgranicznie w aktorów jako „oryginalnych twórców”:

pierwszą funkcją reżysera jest komunikacja z aktorem. Dyskutujesz o dialogach, zgadzasz się na sytuację $\mathrm{w}$ dramacie - a potem oddajesz to aktorowi. [...] Kiedy coś się wydarza na próbach, czego nie kontroluję, kiedy coś się uwalnia w aktorach, wtedy z rozkoszą opuszczam salę prób. Nie czynię tego z uczuciem „świetnie, to moje koncepcje” (Ostermeier 1998a: 30).

\footnotetext{
5 Użyłem terminu „neo(n)realism" w: Boenisch 2010: 339-357. W tym rozdziale dokonuję rewizji i rozwinięcia niektórych argumentów i analiz zawartych w tamtym tekście.

${ }_{6}$ Tekst został pierwotnie opublikowany pt. Der Auftrag w broszurze programowej zapowiadającej sezon wiosenny 2000 w Schaubühne am Lehniner Platz.

7 Czerpiąc z publikacji Rudolfa Münza i Helmara Schramma, odróżniam „theatrality” wskazującą na „magiczną grę" teatru od "theatricality”, która jest związana z oszustwem i podróbką. Zob. Boenisch 2015: 33-53.
} 
Zamiast nakładać swoją wizję i swoje koncepcje na dramat, co Ostermeier nazywa „dedukcyjną metodą reżyserowania” [...], podąża za zasadą reżyserii „indukcyjnej”. Do Brechtowskiego zaangażowania politycznego dodaje podejście estetyczne wywiedzione z tradycji Maxa Reinhardta, a oparte na założeniu, że każdy dramat wymaga specyficznego reżyserskiego podejścia i sposobu inscenizowania. Rozwija Reinhardtowskie wyczucie fascynującej, chwilami widowiskowej, a z pewnością popularnej i dostępnej teatralności. Twórczość Ostermeiera składa w ten sposób hołd reżyserom teatru, łącząc dwie niemieckie tradycje reżyserii zdefiniowane przez Reinhardta (mówiąc dosadnie, „niemieckiego Stanisławskiego") i Brechta, z amalgamatem bardzo konkretnej psychofizycznej techniki Meyerholda i wizjonerskiego „okrucieństwa” Artauda, które mogą pośredniczyć w połączeniu tych dwóch tradycji ${ }^{8}$.

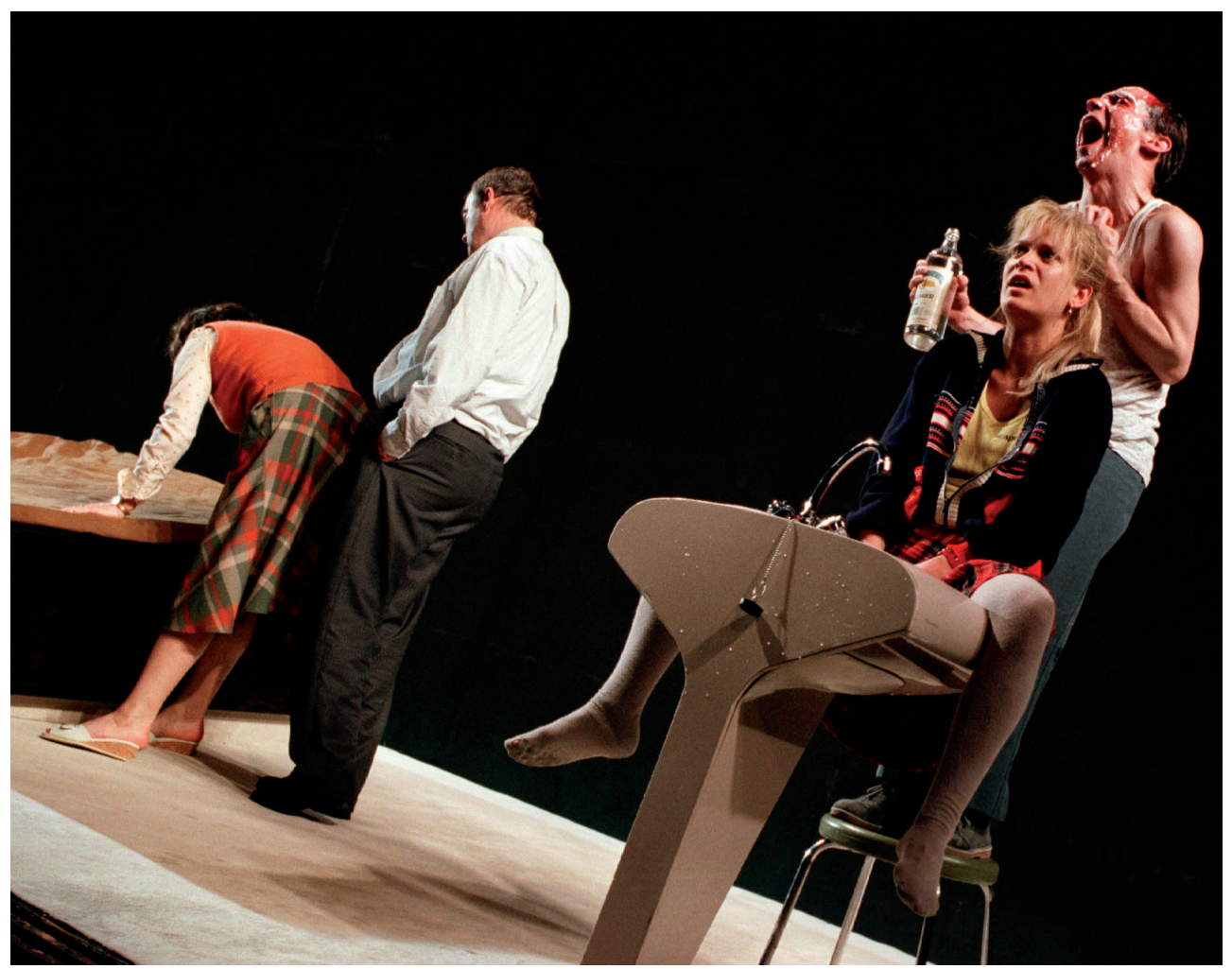

Robert Bayer (Kurt) i Judith Engel (Olga) w Ogniu w glowie M. von Mayenburga w reż. Thomasa Ostermeiera

Fot. Wojtek Szabelski. Z archiwum Teatru im. W. Horzycy

8 Myśląc o "reżyserskim bilansie" Ostermeiera w tym czasie, wciąż się zastanawiałem, pisząc w 2008 roku, czy „to nie za wcześnie jeszcze na uznanie Ostermeiera za prawowitego spadkobiercę Reinhardta i Brechta” (Boenisch 2010: 356). 


\section{„Włażąc ludziom w twarz \\ z naszymi gołymi tyłkami”: egzystencjalny teatr w Die Baracke}

Błyskawiczny sukces Thomasa Ostermeiera (Carlson 2009: 161) nastąpił w momencie, gdy był jeszcze studentem reżyserii w Hochschule für Schauspielkunst „Ernst Busch” w Berlinie, najważniejszej akademii teatralnej w NRD, której udało się pozostać główną i znaczącą szkołą w Niemczech do dziś dzięki podążaniu za rozpoznawalną „wschodnioeuropejską" pedagogiką teatralną w tradycji Stanisławskiego, Meyerholda, Eisensteina i Brechta9. W 1996 roku Michael Ebert, wtedy ustępujący główny dramaturg Deutsches Theater w Berlinie, zapewnił grant od uczelni na przebudowanie zużytej drewnianej chaty obok teatru, w której czasami odbywały się warsztaty, mieściła się kantyna i magazyn, w małą scenę służącą wystawianiu nowych, eksperymentalnych przedstawień. Znając studenckie prace Ostermeiera, zwrócił się do niego z propozycją uruchomienia tej sceny pod nazwą „Die Baracke” (dosłownie: barak). Eberth, który sam odszedł wtedy z Deutsches Theater, zostawił Ostermeierowi stertę scenariuszy i przekładów - ich inscenizacje szybko uczyniły z małej, improwizowanej i raczej walącej się przestrzeni scenę znaną daleko poza Berlinem. Inscenizacja Fat Men in Skirts nowojorskiego dramatopisarza Nicky'ego Silvera zainaugurowała działalność Die Baracke w grudniu 1996 roku, później swoje premiery miały Noże w kurach Davida Harrowera, Shopping and Fucking Marca Ravenhilla, sztuki Martina Crimpa, Endy Walsh i last but not least Sarah Kane. Między jesienią 1996 i latem 1999 roku zrealizowano tu osiem nowych spektakli, z których siedem wyreżyserował Ostermeier wspierany przez dramaturga Jensa Hillje (chodził z nim do szkoły w rodzinnym bawarskim Landshut) i scenografa Jana Pappelbauma, który przekształcił drewnianą chatę w zmienną, pustą przestrzeń, dodając przenośne kontenery jako garderoby i biuro z tyłu. Mieli ograniczone finansowe i techniczne wsparcie z Deutsches Theater, byli skrępowani limitowaną dostępnością aktorów z zespołu DT, co oznaczało niedużą liczbę możliwych przedstawień. Dlatego też prowadzili Die Baracke raczej jako subkulturowe centrum sztuki, organizując obok spektakli czytania performatywne, wystawy, dyskusje polityczne i koncerty, włączając w to występy własnego zespołu punkrockowego Ostermeiera, w którym grał na gitarze basowej.

Zrywając z elitarnością i konserwatyzmem, z którymi była kojarzona większość teatrów w mieście, założyli teatr otwarty, kuszący, dostępny dla wszystkich. Kontynuującej trend zainicjowany kilka lat wcześniej przez równie alternatywną i odnoszącą sukcesy Volksbühne Franka Castorfa, Die Baracke udało się zmienić teatr w miejsce „hip” i „cool”

9 W wywiadzie po francusku z 2001 roku Ostermeier skorygował skojarzenie jego pracy z zachodnioniemiecką tradycją Regietheater, związaną z byłym liderem Schaubühne Peterem Steinem. Przywołał natomiast jako dziedzictwo formacyjne twórczość kilku wschodnioniemieckich artystów teatru, o których uczył się w ErnstBusch-Schule: „Porównanie z Peterem Steinem w ogóle nie jest trafione - mój teatr jest całkowicie inspirowany tradycją Berliner Ensemble: dziełami Matthiasa Langhoffa i Manfreda Kargego, a nawet Benno Bessona" (Pelechová 2013: 84, tłum. P. M. Boenisch). Max Reinhardt, niegdysiejszy dyrektor Deutsches Theater (którego dyrekcja uruchomiła Die Baracke pod swoimi skrzydłami), a także założyciel pierwszej szkoły teatralnej, w której swoich korzeni upatruje dzisiejsza Ernst-Busch-Schule, podtrzymująca swoje tradycyjnie bliskie związki z DT. 
przyciągające tłum młodej, modnie ubranej, głównie dwudziestoletniej młodzieży. W końcu zespół Die Baracke otrzymał propozycję objęcia prestiżowej Schaubühne, która stała się sławna dzięki Peterowi Steinowi w latach 70. XX wieku. Ostermeier zgodził się i postanowił wystartować wspólnie z choreografką Sashą Waltz i jej partnerem, producentem Jochenem Sandigiem. Współpraca trwała do $2005 \mathrm{roku}^{10}$. Wpisując się precyzyjnie w początek nowego tysiąclecia, wspólnie przenieśli się w styczniu 2000 roku ze swoich prowizorycznych kwater w dawnym wschodnim Berlinie do imponującego budynku w stylu Bauhausu, zaprojektowanego przez Ericha Mendelssohna na Lehniner Platz w zamożnej (zachodniej) dzielnicy Berlina Charlottenburg. Ostermeier miał wtedy trzydzieści dwa lata - tyle samo, ile Peter Stein, kiedy obejmował tę scenę w latach 70 .

Ostermeier zadedykował Die Baracke „materii, która jest istotna”, i „teatrowi, który nas interesuje" (Ostermeier 1998b: 24). Afiliacja przy Deutsches Theater pozwoliła mu zrealizować te cele, mógł pracować z aktorami z jednej z najlepszych scen w Niemczech, takimi jak Thomas Bading, który dziś należy do zespołu Schaubühne jako jeden z kilku długoletnich członków zespołu Ostermeiera, podążający za dyrektorem od czasu jego wczesnych przedstawień ${ }^{11}$. Bading był już sporo po trzydziestce, kiedy zagrał rolę Marka w legendarnej inscenizacji Shopping and Fucking, która stała się dziełem rozpoznawczym Die Baracke, a potem trafiła do repertuaru Schaubühne, gdzie w 2008 roku świętowała swoją dziesiątą rocznicę premiery. Aktor przypomina pracę z Ostermeierem w Die Baracke i przenosiny do Schaubühne w niedawnej rozmowie:

W Die Baracke Thomas [Ostermeier] był bardziej naiwny, agresywny, bardziej egzystencjalny i szalony. Był zdolny zrobić wszystko, ponieważ Die Baracke zaczynała jako teatr bez nazwy i nie była zobligowana do wypełnienia widowni. Wolny od jakiejkolwiek presji tworzył dzieła, które były bardzo świadome społecznie, a przede wszystkim bardzo niepokojące. Zawsze graliśmy postaci na krawędzi: postaci na marginesie społeczeństwa, na skraju społecznego upadku i nędzy, a czasami u końca ich życia - na krawędzi śmierci. To określam mianem „egzystencjalny". Pierwsze lata w Schaubühne były podobne. W Personenkreis 3.1 Norena wszyscy graliśmy bezdomnych i ćpunów.

$\mathrm{W}$ tamtym czasie dosłownie wskakiwaliśmy ludziom $\mathrm{w}$ twarze naszymi gołymi tyłkami. To był najbardziej bezkompromisowy teatr, który doprowadzał widzów do zasłabnięcia w każdym spektaklu - nasz rekord w Shopping and Fucking to osiem omdleń w czasie jednego wieczoru, wśród tylko 99 osób na widowni! Kiedy przeszliśmy tutaj [do Schaubühne] myśleliśmy, że to się nie zdarzy w przestrzeni z pięciuset miejscami i klimatyzacją - ale się zdarzało, ludzie wciąż mdleli podczas spektakli, taki to był agresywny, mocny teatr. Dotychczasowa widownia Schaubühne była oczywiście zbulwersowana i przestali przychodzić. To pozwoliło nam znaleźć w kilka lat nowych widzów, musieliśmy się nauczyć tworzyć sztukę, która nie uderza naszych widzów pięścią w twarz, lecz w zamian za to uwodzi i przyciąga na różne sposoby, które pasują do miejscowych warunków. Niektórzy mogą powiedzieć, że teatr Thomasa stał się bardziej przyjemny i płytki, ale nie - po prostu nie możesz wciąż patrzeć na widzów wychodzących

10 Waltz i Sandig założyli równie innowacyjną kuźnię sztuk performatywnych w Sophiensäle, budynku byłego związku zawodowego, który odgrywał istotną rolę w historii berlińskiego ruchu robotniczego na przełomie XIX i XX wieku.

11 Obok Badinga byli to Jule Böwe, Kay Bartholomäus Schulze oraz koledzy Ostermeiera z Ernst-Busch-Schule Robert Beyer i Mark Waschke, podczas gdy koleżanki ze studiów Ursina Lardi i Nina Hoss wcześniej dołączyły do zespołu Schaubühne. 
z przedstawienia lub słabnących, więc znalazł sposoby na to, aby jego spektakle wchodziły pod skórę, ale bez włażenia z tyłkiem w twarze ludzi ${ }^{12}$.

Co się nie zmieniło po zwrocie Ostermeiera od spektakli bezkompromisowych, raczej literalnie brutalistycznych, do formalnie bardziej zamkniętych inscenizacji ostatnich lat, takich jak Little Foxes Hellman (2014) i Bella Figura Yasminy Rezy (2015, z tekstem specjalnie napisanym dla reżysera i zespołu Schaubühne), to realistyczna postawa, poprzez którą jego produkcje niczym sejsmograf zapisują kronikę niemieckiego społeczeństwa. Jak Ostermeier przeniósł się z pozycji „bezimiennego outsidera” w centrum niemieckiego establishmentu teatralnego z Schaubühne u steru, tak akcent $\mathrm{w}$ jego teatrze przesunął się z radykalnego, wstrząsającego „realizmu wyrzutka” ku bardziej bezpośrednio rozpoznawalnej „rzeczywistości ludzi tego wieku, z tej klasy społecznej”, jak powiedział w 2005 roku w rozmowie z katalońskim reżyserem Alexem Rigolą. Prawie ekskluzywne skupienie na nowej dramaturgii w czasach Die Baracke i początkowych latach w Schaubühne otworzyło drogę do eksploracji tekstów klasycznych, które dostarczają Ostermeierowi odgłosów obecnego, „relewantnego” materiału. Ten rozwój można zauważyć w czasie od jego inscenizacji Śmierci Dantona z 2001 roku do kulminacji w głównym cyklu inscenizacji dramatów Ibsena i Szekspira.

\section{Zwrot Ostermeiera do sztuk klasycznych: opowiadanie historii o nas i otchłani wypartych emocji}

Czy to przenosząc living roomy Nory, Heddy Gabler albo doktora Stockmanna prosto do odnowionych mieszkań w zamożnej berlińskiej dzielnicy Mitte, czy wprowadzając wytwory współczesnej kultury w otwarte przestrzenie teatralne swojego Hamleta, Otella, Miarki za miarkę oraz Ryszarda III, Ostermeier wystawia kanoniczne dramaty tak, abyśmy skierowali nasze refleksje na samych siebie i nasz świat raczej, niż byśmy mieli empatycznie wspól-czuć z postaciami w fikcyjnym świecie, który oglądamy z bezpiecznego dystansu. Jak argumentuje Ostermeier: „Fundamentalna rola teatru w naszej kulturze polega na opowiadaniu historii o nas, o naszym życiu, problemach i naszym społeczeństwie. Dlatego teatr istnieje. Postaci na scenie są naszymi reprezentantami, którzy działają, podejmują decyzje w naszym imieniu" (Boenisch, Ostermeier 2016: rozdz. 6).

W teatrze Ostermeiera wystawiane teksty dostarczają więc (dramatycznej) narracji, której konstytutywne sytuacje są wykorzystywane w grze teatralnej, tak że oferują wzorce egzystencjalnych konfliktów w obrębie naszych społeczeństw. Konflikty są wielopostaciowe i nie dają się zredukować do pojedynczych „tematów”, które mogłyby być udramatyzowane w izolacji. Postaci nie są widziane jako byty psychologiczne, z którymi publiczność ma odczuwać empatię, lecz jako istoty działające w ramach tych modelowych sytuacji, a ich

12 Rozmowa z Thomasem Badingiem w maju 2015 roku. 
zdolność działania jest symultanicznie determinowana przez tę sytuację. Nawiązałem kiedyś do pojęcia Raymonda Williamsa „struktura emocji” (structure of feeling) wywodzącego się z zakresu materializmu kulturowego, aby zarysować zarówno polityczne, jak i etyczne jądro twórczości Ostermeiera (Boenisch 2010: 344). Termin Williamsa uwydatnia cielesne i zmysłowe uwikłanie jednostki w jej bezpośrednim socjokulturowym i ekonomicznym kontekście, tym samym wyróżnienie roli aktualnego doświadczenia w kształtowaniu znaczenia i Marksowskiej „świadomości”. Stałą cechą twórczości Ostermeiera - obecną w jego spektaklach i sposobie reżyserowania - jest wspólna „struktura emocji” (zamiast samego Zeitgeist), która istotnie przyczynia się do efektu R(ealizmu) w jego teatrze poprzez ustanowienie bezpośrednich afektywnych połączeń z widownią i w ten sposób prowokowanie rozpoznań u widzów. Wspólna „struktura emocji” (zamiast podejścia psychologicznego) jest także przywoływana na próbie, aby pomóc jego aktorom w otwarciu ich postaci. W rezultacie teatr Ostermeiera odzwierciedla także emocjonalną wrażliwość jego generacji, „pierwszego pokolenia w Niemczech, które z pewnością nie chce być lepsze niż ich rodzice” (Jörder 2014: 87). Jego twórczość odzwierciedla trajektorię przemiany energetycznego, hedonistycznego, pozjednoczeniowego „Pokolenia Golfa” (Generation Golf) lat 90. w dotknięte kryzysem, pogrążone w stagnacji i konserwatywne „Pokolenie Strachu” (Generation Angst), nawet bardziej takie właśnie w ostatnich latach globalnego i (nie tylko) finansowego niepokoju ${ }^{13}$. W wywiadzie z 2014 roku, spoglądając w przeszłość, Ostermeier opisuje to jako własne (jego skromnym zdaniem: jedyne) osiągnięcie - ukazanie na scenie mentalności nowego mieszczaństwa reprezentowanego przez jego rówieśników:

To pokolenie jest przekupne; każdy chce tylko pieniędzy, sukcesu i bezpieczeństwa. Pragnienie powrotu do domu wieczorem, zanurzenia się w chronionym gnieździe, to wycofanie się ze społeczeństwa, ten strach przed niemożnością zdobycia wolności ... (Jörder 2014: 9 i 23).

Klasycy - a dramaty Ibsena w szczególności - nie stanowią celu samego w sobie, lecz dokładają do środków teatralnych będących w dyspozycji reżysera możliwość zbadania „struktur emocji” charakterystycznych dla „nowego mieszczaństwa”. Ostermeier nigdy nie był za „współczesną” interpretacją klasyki, lecz przede wszystkim za interpretacją społeczeństwa i otchłani jego wypartych emocji, do której np. Szekspir daje możliwość dotarcia.

W swoim estetyczno-politycznym dążeniu do wystawiania dramatów o niemieckiej klasie średniej w jej wędrówce przez wiek XXI Ostermeier znajduje sojuszników nie tyle w reżyserach teatralnych, ile filmowych, takich jak Michael Haneke, Hans-Christian Schmid czy Christian Petzold. W wywiadzie z 2014 roku połączył sam siebie ze wzorcem, który rzadko pojawiał się dotychczas w kontekście jego twórczości - amerykańskim reżyserem kina artystycznego Johnem Cassavetesem:

On ujmuje to prawidłowo! Jego filmy świetnie oddają portrety tych mieszczan, drobnomieszczańskich światów; dokumentują kontrowersje interpersonalne, prowadzą w głęboką otchłań, ale nigdy w wymuszony sposób lub ze względu na chęć pokazania horroru (Jörder 2014: 23).

13 Pokolenie zachodnich Niemców, które dorastało w latach 70. i 80. i czerpało korzyści z boomu gospodarczego po zjednoczeniu, zawdzięcza swoją nazwę książce Generation Golf dziennikarza Floriana Illiesa urodzonego w 1971 roku; tytuł nawiązuje do marki samochodu Volkswagen Golf, a nie do dyscypliny sportu. 
Inaczej niż wielu współczesnych reżyserów, Ostermeier nigdy nie okazywał skłonności do przeniesienia kina artystycznego na scenę teatralną, z wyjątkiem Małżeństwa Marii Braun Wernera Fassbindera, lecz nawet tutaj pracował ze scenariuszem Petera Märtesheimera i Pei Fröhlich i twierdzil, że obejrzał film ponownie dopiero po premierze spektaklu. Bardziej niż małpowanie zdolności kina na użytek przedstawienia, Ostermeiera interesuje w teatrze danie widzom doświadczenia, które odzwierciedla ich przyzwyczajenia percepcyjne. Jego teatr mówi językiem i formami, z jakimi publiczność jest oswojona; określenie „pop” często jest nadużywane w recenzjach i analizach jego dzieł. Jednak choć filmowy tryb narracji mocno wpływał na jego sposób wystawiania nowych dramatów i kanonicznych dzieł klasycznych na scenie - używa krótkich ujęć scenicznych i szybkiego tempa narracji, wplata w spektakle rozpoznawalne piosenki rockowe i popowe, jak też projekcje wideo - to jednak Ostermeier używa tych nowoczesnych środków ekspresji tylko po to, żeby podkreślić i rozszerzyć niepowtarzalną jakość aktorstwa i teatru na żywo. Wraz z wyrazistą grą aktorów te środki są skrupulatnie wplatane w precyzyjnie wyznaczony rytm teatralny. Kombinacja bezkompromisowej współczesności z teatralnym warsztatem i techniką stanowily - i wciąż stanowią - formułę przynoszącą Ostermeierowi sukces; to właśnie ta mieszanka pokonała uprzedzenia młodszej publiczności uznającej teatr za „konserwatywny”, „elitarny” czy „nie dla nich”, dzisiaj Schaubühne przyciąga szeroką pod względem rozpiętości wieku widownię.

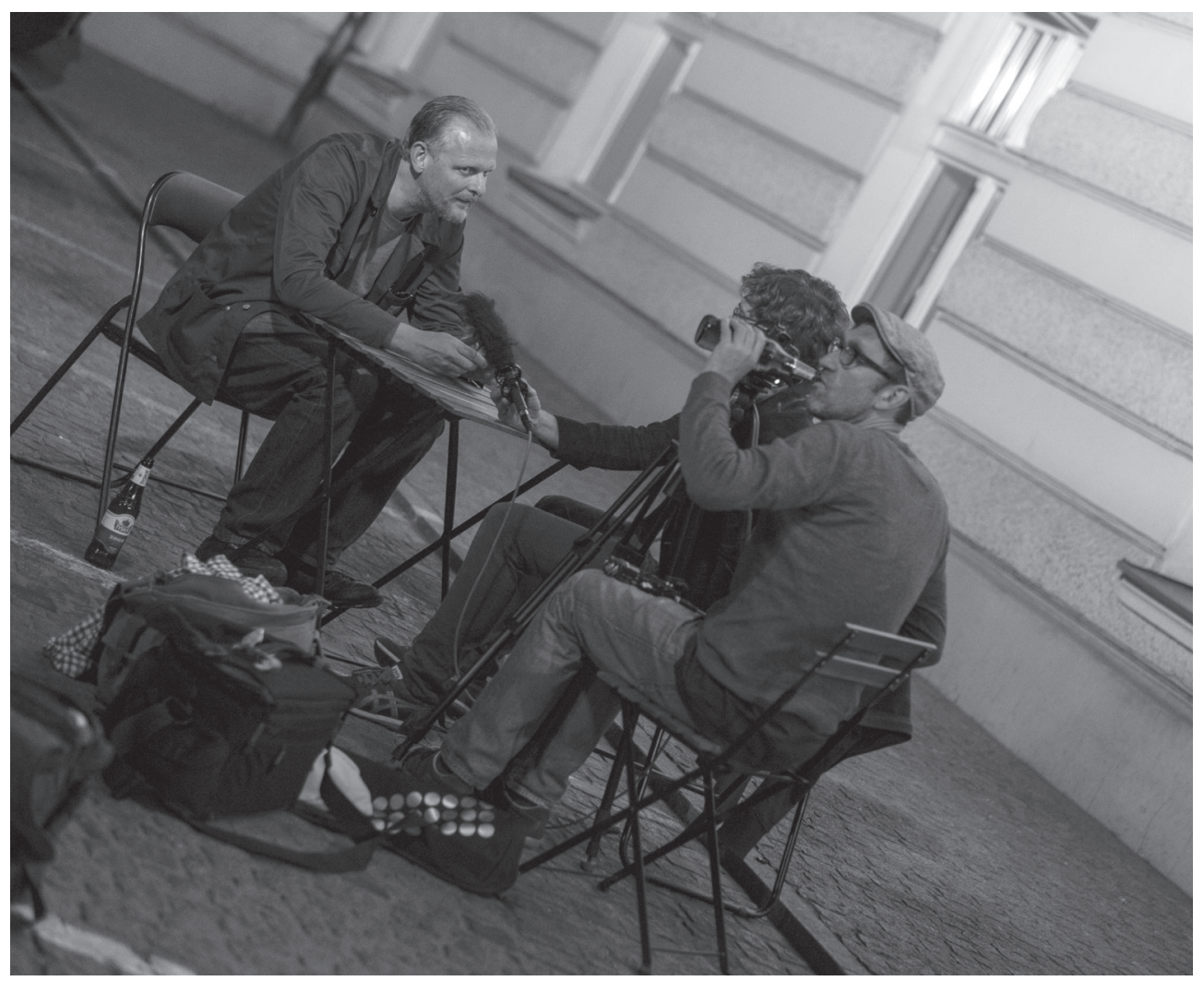

Thomas Ostermeier udziela wywiadu niemieckiej telewizji w Toruniu Fot. Wojtek Szabelski. Z archiwum Teatru im. W. Horzycy 


\section{Laboratorium poszukiwania nowych metod reżyserskich}

W czasie swojej kariery Ostermeier poświęcał wiele uwagi technice reżyserowania. Prowadząc próby, koncentruje się na niuansach sposobu wypowiadania kwestii lub na tonie głosu aktora i komponuje drobiazgowo powtarzalny wzorzec napięć i rozluźnień, mowy, akcji, pauz, wybuchów, szalonego tempa, powolności, ogłuszającego hałasu, momentów ciszy, szerokich i subtelnych gestów. Ten sceniczny rytm jest inspirowany klasyczną ideą montażu atrakcji Siergieja Eisensteina. Już wczesne spektakle w Die Baracke pokazywały mocne wyczucie efektywnie skonstruowanych dzieł scenicznych, eksponowania cielesności i rytmicznego punktowania. Rzeczywiście obok nowej dramaturgii to precyzyjne użycie aktorstwa i technik scenicznych przyczyniło się w istotnym stopniu nie tylko do nowatorstwa jego dzieł, lecz nawet bardziej do czasami obezwładniającego, afektywnego wpływu tych spektakli na publiczność, jak zauważył Thomas Bading w komentarzu cytowanym wyżej. Na przykład rozegrana w zupełnej ciszy, ale poruszająca trzewia scena, która doprowadzała widzów do łez w Shopping and Fucking. O ile dramat Marka Ravenhilla pokazuje młodą męską prostytutkę Gary'ego, który zaprasza Marka do spenetrowania go nożem, i potem urywa nagle tę scenę, przechodząc do następnej, o tyle w spektaklu Ostermeiera scena sadystycznego seksu zostaje pokazana w całości i niemal w slow-motion. Ta niekończąca się, bezsłowna, cielesna, a nie psychologizowana scena, z całą wściekłością, frustracją, desperacją i głodem miłości, wszystkimi „realnymi” wymiarami wrażliwości, napędzającymi działania postaci, została zagrana w sposób, który jest charakterystyczny dla jego teatru do dzisiaj. To właśnie dzięki metodycznemu wyjściu poza empatię i litość oraz odwołaniu do czysto afektywnej sfery scena ta stała się tak intensywna i bulwersująca (Boenisch 2010: 353-355).

Wiele spektakli Ostermeiera $\mathrm{z}$ ostatnich dwudziestu lat można postrzegać jako kontynuację poszukiwań nowych metod reżyserowania w kontekście kultury XXI wieku. Jego spotkania z Artaudem, Stanisławskim i Meyerholdem, w szczególności podczas studiów w Ernst-Busch-Schule na zajęciach z byłym aktorem i reżyserem Berliner Ensemble Manfredem Karge, były pierwszym doświadczeniem formującym. Pierwszy spektakl Ostermeiera dla Die Baracke przy Deutsches Theater prowadzonym przez intendanta Thomasa Langhoffa i dramaturga Ebertha odzwierciedlał już to zainteresowanie teorią teatru praktycznie poszukującego: zamiast przestrzeni zajmującej się nową dramaturgią, dzięki czemu to małe miejsce stało się sławne, początkowo zaproponował urządzenie w Die Baracke „laboratorium metodycznego badania aktorstwa”, wzorowanego na studiach Moskiewskiego Teatru Artystycznego - zamiar Ostermeiera został zrealizowany w pierwszym sezonie działalności Die Baracke w inscenizacji Mann ist Mann Brechta, do której zaprosił rosyjskiego specjalistę od biomechaniki Giennadija Bogdanowa.

Przez lata Ostermeier doskonalił wokalny i fizyczny poziom kreacji swoich aktorów, jak też ich umiejętność pracy zespołowej. W czasach wspólnego prowadzenia Schaubühne z Sashą Waltz jego aktorzy i jej tancerze brali udział we wspólnych sesjach treningowych. Później pochodząca z Argentyny choreografka Constanza Macras oraz dramatopisarz i reżyser Falk Richter na stałe związali się z teatrem. Ten drugi tworzył spektakle w konwencji teatru tańca wspólnie ze swoją długoletnią partnerką Annouk van Dijk, wchodząc także na 
obszar współczesnej opery w inscenizacji For the Disconnected Child (2013), koprodukcji Schaubühne z berlińską Staatsoper. We wszystkich tych przedstawieniach członkowie zespołu Schaubühne występowali wraz z tancerzami i śpiewakami z zespołów Macras, van Dijk i opery. W tym czasie Ostermeier rozwijał własne poszukiwania rytmów scenicznych i afektywnych, które cechują jego inscenizacje. Akcenty w jego pracy dyrektora artystycznego także uległy przesunięciu z obszaru zainteresowania nową dramaturgią, którą zajmował się, gdy nieliczne sceny niemieckie były otwarte na radykalnych, nowych dramatopisarzy. Dzisiaj nowe teksty stały się podstawowym „pokarmem” wielu berlińskich teatrów, od Deutsches Theater po Maxim-Gorki-Theater, prowadzony przez byłego współpracownika Ostermeiera Jensa Hillje wspólnie z Shermin Langhoff. Ostermeier natomiast steruje swoją Schaubühne w stronę, w którą kiedyś miała zmierzać Die Baracke - ku radykalnemu Regietheater XXI wieku. Zamiast zatrudnić grupę stałych reżyserów, zaprasza (uzupełniając swój własny styl reżyserski) uznanych na świecie artystów do regularnej współpracy z aktorami Schaubühne, którym otwiera możliwość zmierzenia się z całą paletą wyzwań, rozwoju ich warsztatu i talentu. W ostatnich latach reżyserzy, tacy jak Katie Mitchell, Romeo Castelucci, Alvis Hermanis, Ivo van Hove, Michael Thalheimer, Nicolas Stemann i - po raz pierwszy w 2015 roku - Simon McBurney, realizowali spektakle z jego zespołem, kontynuowana jest ponadto długoletnia współpraca z Falkiem Richterem, Mariusem von Mayenburgiem i Patrickiem Wengenrothem. Schaubühne stała się tym laboratorium, o którym Ostermeier myślał kiedyś, ale nieskupiającym się wyłącznie na metodycznym badaniu aktorstwa czy nowej dramaturgii, lecz na „nowych reżyseriach” i bardziej generalnie na systematycznej eksploracji różnych środków współczesnego teatru.

$[\ldots]^{14}$

Refleksja Ostermeiera i jego eksploracje teatru, warsztatu aktorskiego, praw, mechanizmów i technik zawsze pozostawały na służbie społecznych i politycznych funkcji teatru, do którego aspiruje. Nie inaczej niż u Brechta celem wszystkich tych elementów jest asystowanie w tworzeniu rozrywkowej, dostępnej i pełnej znaczeń sztuki teatru, która umiejętnie prowokuje widzów do rozpoznania własnej sytuacji i rozmyślań o własnym życiu. Cel, do którego zmierza jego teatr od dwudziestu lat, określił Ostermeier na początku swojej kariery, poddając refleksji kulturową rolę kina w ogóle lub kina wartego odwiedzania. W swoim artykule z 1999 roku Teatr $w$ epoce jego przyspieszenia stwierdził, że w tamtym czasie nie teatr, lecz kino było

miejscem, które odwiedzałem [...] kiedy chciałem się czegoś nauczyć o życiu. Miejscem, gdzie jestem w stanie zdobyć doświadczenie, które stanowi wyzwanie dla mojego stylu życia, zachęcić mnie do myślenia w inny sposób, innego zrozumienia rzeczy, działania, życia inaczej i bycia innym - ponieważ ktoś pokazuje mi świat w sposób, którego nigdy nie widziałem i odkrywa zupełnie nowy dla mnie świat (Boenisch, Ostermeier 2016: 38).

Jednym słowem i w jakimś stopniu ex negativo, ponieważ właściwie opisał efekt oddziaływania kina na siebie, Ostermeier wyraża w tej wypowiedzi dość precyzyjnie ostateczny ideał, który chciałby zrealizować za pomocą realizmu teatralnego, czy to wystawiając nowy dramat, czy klasyczne dzieło $\mathrm{z}$ kanonu Zachodu, pchając tyłki aktorów w twarze widzów

\footnotetext{
14 Opuszczony fragment dotyczył zawartości całej książki Petera M. Boenischa i Thomasa Ostermeiera.
} 
albo produkując przyjemne według niektórych przedstawienia: zmienić teatr $\mathrm{w}$ miejsce, które - będąc „cool”, otwartym i zachęcającym, tak jak Die Baracke w swoim czasie - zachęca widzów do zmiany sposobu myślenia i kwestionuje ich sposób widzenia świata.

Tłum. z języka angielskiego Artur Duda

\section{Bibliografia}

Boenisch, Peter M. 2010. „Thomas Ostermeier: Mission ne(n)realism and a theatre of actors and authors". W: Maria Delgado, Dan Rebellato (red.). Contemporary European Theatre Directors. Abingdon-New York: Routledge.

-2015. Directing Scenes and Senses: The Thinking of Regie. Manchester: Manchester University Press.

Burckhardt, Barbara 1998. „Der Bassist als erste Geige: Ein Meister-Musterschüler will zurück zu den Wurzeln und ganz nach oben - Thomas Ostermeier, Nachwuchsregisseur des Jahres“. Theater heute Jahrbuch 1998

Carlson, Marvin 2009. „Thomas Ostermeier”. W: Idem. Theatre is more beautiful than war: German stage directing in the late twentieth century. Iowa City: University of Iowa Press.

Jörder, Gerhard 2014. Backstage Ostermeier. Berlin: Verlag Theater der Zeit.

Lebert, S. 2011. „Thomas Ostermeier. Der Radikale”. Die Zeit 50.

Ostermeier, Thomas 1998a. „Ich muss es einfach versuchen. Rozmowa Theater heute $\mathrm{z}$ Thomasem Ostermeierem". Theater heute 5.

— 1998b. „Auf der Suche nach dem Trojanischen Pferd. Ein Theater heute-Gespräch”. Theater heute Jahrbuch.

Pelechová, Jitka 2013. Le Théâtre de Thomas Ostermeier. Louvain: Louvain-la-Neuve: Centre d'études théâtrales.

Tageszeitung 2000. „Wir müssen von vorn anfangen”. Tageszeitung 20.01. 